\title{
Comparative analysis of the effect of 6-azacytidine, ribavirin and cyclocytidine on the synthesis of adenoviral polypeptides
}

\author{
L. N. Nosach ${ }^{1}$, L. S. Usenko², I. V. Alexeeva ${ }^{2}$ \\ ${ }^{1}$ D. K. Zabolotny Institute of Microbiology and Virology, NAS of Ukraine \\ 154, Academika Zabolotnogo Str., Kyiv, Ukraine, 03143 \\ 2 Institute of Molecular Biology and Genetics, NAS of Ukraine \\ 150, Akademika Zabolotnoho Str., Kyiv, Ukraine, 03143 \\ i.v.alexeeva@imbg.org.ua
}

\begin{abstract}
Aim. Comparative study of the effect of antiviral nucleoside analogues 6-azacytidine (6-azaC), ribavirin (Rbv) and cyclocytidine (CycloC) on the synthesis of adenoviral (ADV) polypeptides in cell cultures. Methods. Luminescent microscopy, immunofluorescent assay of hexon antigen, SDS-polyacrylamide gel electrophoresis of ${ }^{14} \mathrm{C}$-labeled proteins. Results. 6-AzaC and $\mathrm{Rbv}$ are able to block completely the expression of adenoviral genome, switching off the synthesis of both early and late structural viral polypeptides. Rbv can also inhibit the formation of immunologically active hexon trimers and intranuclear inclusion bodies of the late type. The effect of CycloC on the functional activity of adenoviral genome is different: it is able to completely block the late, but not early function of the viral genome associated with the synthesis of $72 \mathrm{~K}$ DNA-binding protein. The synthesis of this protein stopped only after the synthesis of the whole spectrum of polypeptides of structural proteins. Conclusion. The peculiarities of the effect of nucleoside analogues on the synthesis of adenoviral polypeptides were established. All studied nucleosides are able to suppress the synthesis; however, the specific profiles of their biological activity are determined by the structure and concentration of the compounds.
\end{abstract}

Ke y w o r d s: adenovirus, 6-azacytidine, ribavirin, cyclocytidine, viral polypeptides

\section{Introduction}

Human adenoviruses (ADV) are non-enveloped DNA-genome viruses with a broad spectrum of pathogenicity. They are able to cause a number of infectious diseases characterized by varying severity of the lesions affecting the respiratory, gastrointestinal and urogenital tracts, as well as the surface of the eye. They are most dangerous for patients with immunodeficiency and for transplant recipients due to the development of generalized adenovirus

C 2020 L. N. Nosach et al.; Published by the Institute of Molecular Biology and Genetics, NAS of Ukraine on behalf of Biopolymers and Cell. This is an Open Access article distributed under the terms of the Creative Commons Attribution License (http://creativecommons.org/licenses/by/4.0/), which permits unrestricted reuse, distribution, and reproduction in any medium, provided the original work is properly cited 
infection, which frequently leads to a lethal outcome [1]. ADV are able to persist in the organism in a latent state for a long time and can be reactivated by various exo- and endogenous factors.

Currently there are no approved efficient therapeutic agents against ADV infections. Thus, new antiviral agents with potential activity against ADV are increasing needed. Several laboratories have determined the anti-ADV activity of nucleoside analogues ([1] and references therein). In particular, ribavirin and cidofovir have been used in the treatment of ADV infections, yet with variable results.

Previously we have investigated the antiadenoviral activity of 6-azacytidine (6-azaC), a structural analogue of cytidine, and its derivatives. 6-AzaC has strong anti-adenoviral properties in vitro suppressing the reproduction of ADV types 1, 2 and 5 in HeLa and Hep-2 cells $\left(\mathrm{EC}_{50} 0.5 \mu \mathrm{g} / \mathrm{ml}\right.$, selectivity index 380$)$ [2-6]. Its antiviral effect is expressed by inhibiting the formation of virus-specific intranuclear DNA-containing inclusion bodies, suppressed synthesis of viral DNA, hexon antigen and infectious virus $[2,3]$. The application of 6-azaC on a model of disseminated ADV infection in newborn Syrian hamsters led to a significant decrease of virus titer and shortening the time of virus clearance in organs $[4,5]$.

Then our interest was focused on the synthesis and comparative study of the anti-adenoviral activity of the novel and already known 6-azaC structural analogues (various D- and L-glycosides of 6-azacytosine, its $\mathrm{N}^{4}$ derivatives, seco- and acyclo-6-azanucleosides) in order to determine the role of various molecular fragments of nucleosides in their inhibitory activity [6-8].

The goal of the present research was a comparative study of the action of three compounds, 6-azaC, the other cytidine analogue cyclocytidine (CycloC) and guanosine analogue ribavirin (Rbv), on the synthesis of viral polypeptides. These nucleoside analogues demonstrate the anti-adenovirus effect [2-6, $9,10]$, but differ in the structure and flexibility of their molecules. This study could possibly discover earlier unknown targets of these antiviral compounds and expand the understanding of the molecular mechanisms of their action.

\section{Materials and Methods}

Anti-adenoviral compounds (Fig. 1). 6-Azacytidine (1- $\beta$-D-ribofuranosyl-6-azacytosine, 6-azaC) was synthesized by us [6].

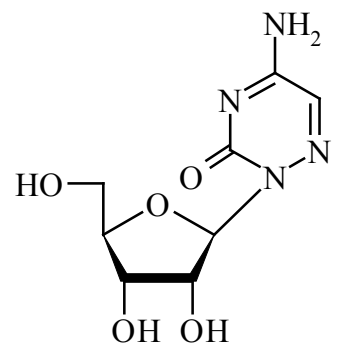

6-azaC

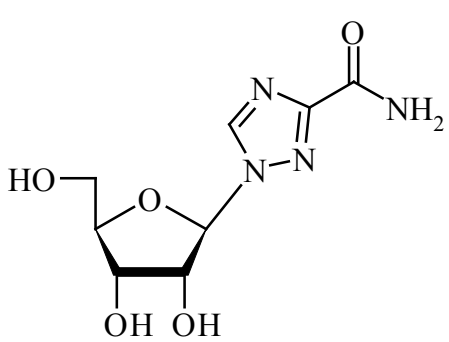

Rbv

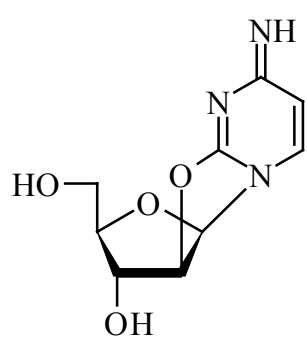

CycloC
Fig. 1. Chemical structures of investigated nucleoside analogues. 
Ribavirin (1- $\beta$-D-ribofuranosyl-1,2,4-triazolyl3-carboxamide, $\mathrm{Rbv})$ and cyclocytidine $\left(\mathrm{O}_{2}, 2\right.$ 'anhydrocytidine, CycloC) were synthesized in the Institute of Organic Chemistry of Latvian Academy of Sciences [10].

Cells and virus. HeLa cells and human adenovirus type 1 (strain Ad71) were obtained within the frame of collaboration with the Institute of Microbiology of Sommelveysa Medical University (Budapest, Hungary).

Cells were grown at $37^{\circ} \mathrm{C}$ as monolayers in tubes with strips of cover glasses or in bottles, using the medium comprising $45 \%$ of medium 199, $45 \%$ of Eagle's medium, and $10 \%$ of heat inactivated bovine serum. Twodays-old cell cultures were infected with adenovirus and incubated for $1 \mathrm{~h}$ at $37^{\circ} \mathrm{C}$. The unabsorbed virus was removed by washing with Hanks balanced salt solution (HBSS). The virus dose was selected in such a way that the virus control represented nearly $80 \%$ cells with virus-specific intranuclear inclusions. The compounds under study, dissolved in the maintenance medium (Eagle's medium without serum), were added at appropriate concentration. The infected cells not treated with the tested compounds were used as a positive control. The cells were incubated for $48 \mathrm{~h}$ at $37^{\circ} \mathrm{C}[4,7]$.

Identification of virus-infected cells. The infected cells growing in tubes with strips of cover glasses and treated or not treated with the assayed compound, were washed with HBSS, fixed with $96 \%$ ethanol, washed with HBSS and stained with $0.01 \%$ acridine orange solution, using HBSS. Cover strips were then mounted on glass slides in HBSS and studied under the fluorescent microscope (Lomo, Russia) for the presence of intranuclear inclu- sions, using the objective $40[6,7,9,11,12]$. The ability of drugs to inhibit the virus reproduction was assessed based on the decrease in the content of the infected cells containing the ADV-induced intranuclear inclusion bodies in treated culture in comparison with untreated one. The cytotoxicity was determined by cytomorphological method and standard MTT test $[4,7]$ after $48 \mathrm{~h}$.

Immunofluorescence analysis. The indirect fluorescent antibody assay was used to reveal the hexon antigen. At $48 \mathrm{~h}$ post-infection, the cells (non treated and treated with tested compounds) were washed with Hanks solution, dried and fixed for $10 \mathrm{~min}$ in ice-cold acetone. Rabbit anti-hexon serum, obtained by us, was used as a primary antibody. The specificity of the sera was tested by precipitation in gel. FITC-conjugated goat anti-rabbit immunoglobulin G (ICN Biochemical, USA) was used as a secondary antibody. The cells were incubated with antibodies at $37{ }^{\circ} \mathrm{C}$ for $45 \mathrm{~min}$. After incubation the cells were washed with HBSS. Cover strips were mounted on glass slides under cover strips with HBSS and examined using the fluorescence microscope. On each of the three slides 500 cells were counted and the percentage of fluorescent cells, containing the hexon antigen in nucleus was determined.

SDS-polyacrylamide gel electrophoresis of labeled viral polypeptides. ADV-infected cells which were treated with 6-azaC, Rbv, CycloC or not treated (positive control of virus infection) were labeled for $1 \mathrm{~h}$ with ${ }^{14} \mathrm{C}$-protein hydrolysate $(15 \mu \mathrm{Ci} / \mathrm{ml})$ at $48 \mathrm{~h}$ after infection. After washing, the cells were scrapped, pelleted by centrifugation and containing $5 \%$ SDS, $10 \%$ 2-mercaptoethanol and 6M urea 
lysis buffer $(50 \mu 1)$ was added to the cell pellet. The samples were boiled at $100{ }^{\circ} \mathrm{C}$ for $3 \mathrm{~min}$ and then analyzed by SDS-PAGE using $6 \%$ concentrating and $12 \%$ separating gel $(30 \mathrm{~V}$, $18 \mathrm{~h}$ ). X-ray film (ORWO, Germany) was used for autoradiography.

\section{Results and Discussion}

In this work, we investigated the action of 6-azaC on the synthesis of adenoviral polypeptides in comparison with that of $\mathrm{Rbv}$ and $\mathrm{CycloC}$, the nucleoside analogues which also demonstrated the anti-adenovirus effect [2-6, $9,10]$, but have different molecular structures (Fig. 1).

The compounds were used in non-toxic concentrations. The maximal tolerated dose was $>500 \mu \mathrm{g} / \mathrm{ml}$ for Rbv and $200 \mu \mathrm{g} / \mathrm{ml}$ for 6-azaC and CycloC $[4,6,7,9]$.

The effect of 6-azaC on the synthesis of adenoviral polypeptides at $48 \mathrm{~h}$ after the infection is shown in Fig. 2. The active synthesis of viral polypeptides was observed in infected cells grown in the absence of tested compounds. Lanes 2 and 9 demonstrate the synthesis of polypeptides of structural ADV proteins which constitute the viral particle and are marked by Roman numerals [13]: II (hexon), III (penton), IV (fiber), V and VII (associated with viral DNA, forming a condensed core structure), IIIa, VI (hexon associated) and nonstructural polypeptide $100 \mathrm{~K}$ participating in the hexon trimerization. The synthesis of these polypeptides in the presence of 6-azaC at concentrations $125,62,31,16$ and $8 \mu \mathrm{g} / \mathrm{ml}$ (lanes 3-7) was completely blocked. As it has been found earlier [3], 6-azaC at the above concentrations inhibited the synthesis of hexon antigen and the formation of intranuclear DNA- containing inclusion bodies, according to the presence of the mature infectious virions. 6-azaC also inhibits the synthesis of adenoviral DNA [2].

Most compounds reported to have antiadenovirus activity are the nucleoside or nucleotide analogues [14-17]. The inhibitory effect is usually realized via their phosphorylation by cellular kinases into the bioactive

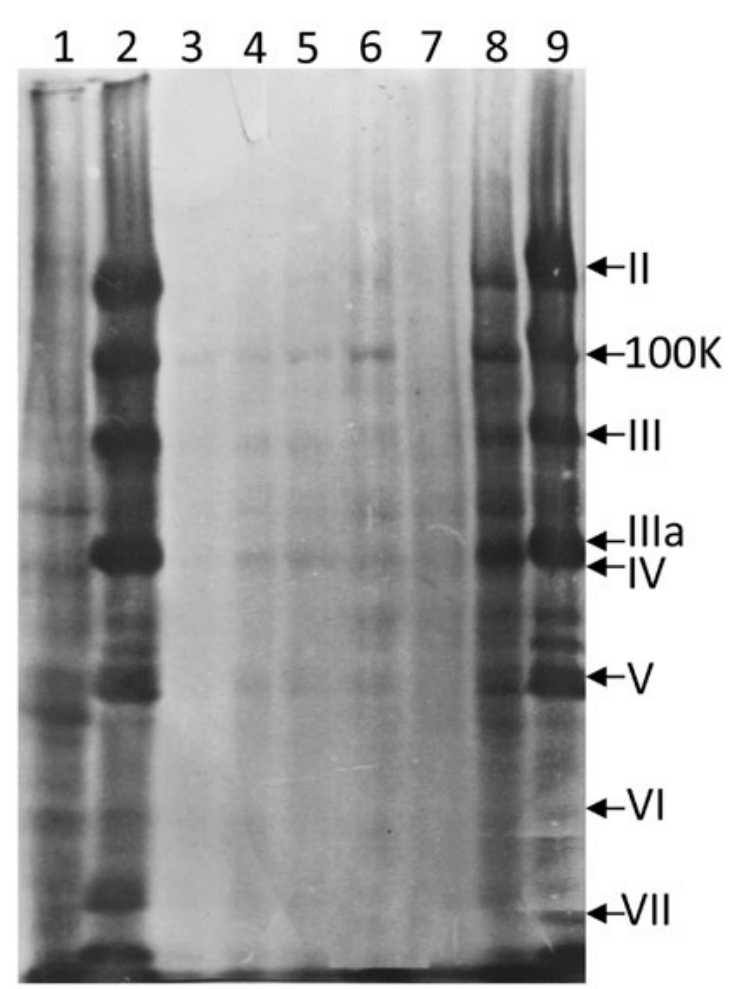

Fig.2. Gel electrophoresis of adenoviral polypeptides synthesized in HeLa cells in the presence of 6-azaC, $48 \mathrm{~h}$ after infection (autoradiogram). Lane 1 - non-infected cells, control; Lane 2 - infected cells, positive control; lanes 3-9 - infected cells treated by 6 -azaC at various concentrations: 125 (3), 62 (4), 31 (5), 16 (6), 8 (7), 1 (8) and $0.1(9) \mu \mathrm{g} / \mathrm{ml}$; II, III, IIIa, IV, V, VI, VII - polypeptides of structural adenoviral proteins; $100 \mathrm{~K}$ - nonstructural viral polypeptide. 
triphosphate forms. The nucleoside triphosphates are able to inhibit adenoviral DNApolymerase by competition with its natural substrates. The 5'-triphosphate form of 2',3'-dideoxynucleoside inhibitors of HIV reverse transcriptase can also inhibit the ADV DNA-polymerase [14-17].

6-azaC, as well as some other cytidine analogues $[14,17]$, is an efficient inhibitor of adenoviral DNA-polymerase preventing the replication of DNA and thus inhibiting the synthesis of late structural polypeptides. However, it was found [18] that 6-azaC was not phosphorylated to a great extent in the cell to become a competitive substrate for DNApolymerase. Apparently, viral DNA is a main target of 6-azaC.

The presence of nitrogen atom at position 6 of triazine aglycone of nucleoside would overcome the obstacle for the rotation around a glycoside bond thus allowing free orientation of carbohydrate and base fragments to expand a set of possible conformers. Increased (in comparison to cytidine) conformational flexibility of 6-azaC was previously confirmed by quantum-chemical techniques. Within the range of relative energies $\Delta \mathrm{E}<8.5 \mathrm{kcal} / \mathrm{mol}$ the molecule may take 11 conformations. Five energetically most advantageous conformers appear to be highly polar structures (dipole moments in the range 4.4-10.4 D), and two of them can be stabilized by the hydrogen bond (O5'H... 2 2) between triazine aglycone and carbohydrate fragments [19]. Perhaps the peculiarities of stereoelectronic structure of 6-azaC molecule allow its efficient interaction with DNA and components of transcription, translation and replication complexes $[19,20]$.
In the studies on the mechanism of 6-azaC interaction with DNA we have previously analyzed its binding to DNA in the presence of well-known intercalating agent, ethidium bromide (EthBr). The spectroscopic study of EthBr-DNA complexes in the presence of 6-azaC showed 6-azacytidine to compete with EthBr for DNA binding sites. Besides, 6-azaC may interact with DNA also by external binding [21]. It was shown that 6-azaC interacts with both native and partially damaged DNA [22].

Ribavirin ( $\mathrm{Rbv}$ ) is a purine nucleoside analogue with a broad spectrum of antiviral activity in vitro against both RNA and DNA viruses, including the adenoviruses [17, 23]. In cytotoxicity assays the confluent monolayers were not destructed and cell morphology was not altered by Rbv at $500 \mu \mathrm{g} / \mathrm{ml}$ concentration. In this concentration Rbv demonstrated the cytotoxicity in MTT test.

Fig. 3 shows the effect of Rbv on the synthesis of structural adenoviral polypeptides at various concentrations. At $250-125 \mu \mathrm{g} / \mathrm{ml}$ concentrations Rbv completely inhibited the expression of adenoviral polypeptides. At lower concentration of $31 \mu \mathrm{g} / \mathrm{ml}$, we observed the synthesis of viral polypeptides, including the hexon polypeptide II. However, the number of cells containing the hexon antigen, which were revealed by immunofluorescence assay using the antiserum to the hexon decreased $\sim 6$-fold ( $13 \%$ vs. $81 \%$ in non-treated cells). Fig. 4D shows the character of distribution of the hexon antigen in the nucleus of infected cells (the dark background shows the specificity of anti-hexon serum). Our data demonstrate that Rbv may affect the formation of immunologically active hexon trimers, although the 


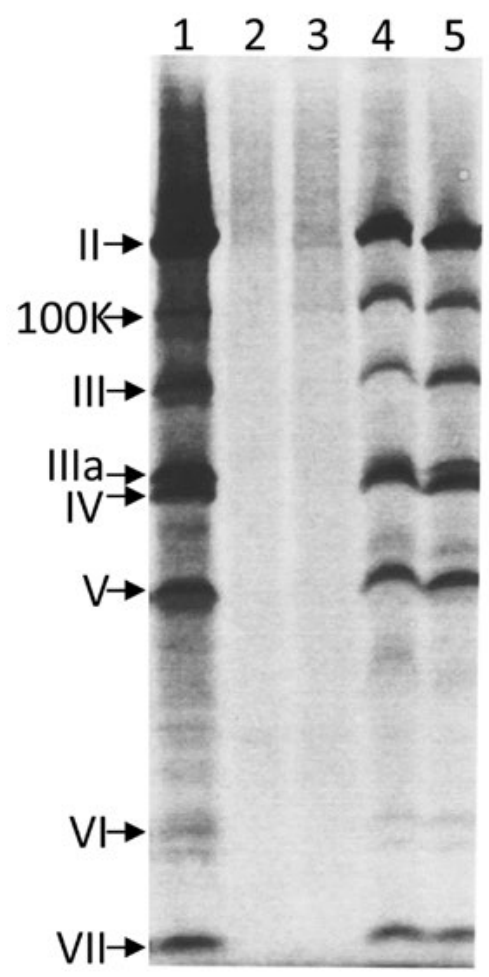

Fig. 3. Gel electrophoresis of adenoviral polypeptides synthesized in HeLa cells in the presence of Rbv, $48 \mathrm{~h}$ after infection (autoradiogram). Lane 1 - infected cells (positive control); lanes 2-5 - cells treated with Rbv: 250 (2), 125 (3), 31 (4), 1 (5) $\mu \mathrm{g} / \mathrm{ml}$; II, III, IIIa, IV, V, VI, VII - polypeptides of structural adenoviral proteins; $100 \mathrm{~K}$ - nonstructural viral polypeptide

synthesis of its monomer form and $100 \mathrm{~K}$ protein participating in the hexon trimerization still takes place. One cannot also exclude the possibility of formation of other proteins with changed structure of several polypeptide chains resulting in the disturbance of virion assembly.

$\mathrm{Rbv}$ is converted into its triphosphate by cellular enzymes. Several mechanisms have been proposed to explain its broad spectrum of antiviral activity [23, 24], including the inhibition of viral polymerases and the inhibi- tion of 5'-cap formation in mRNA that may affect the synthesis of viral polypeptides.

The results of our own studies suggest that the anti-ADV effect of Rbv includes the inhibition of RNA capping. The mechanism is based on structural resemblance of $\mathrm{Rbv}$ to guanosine. Rbv incorporation into the 5'-cap structure of mRNA, instead of normal terminal 7-methylguanosine, may significantly reduce the translation efficiency. Probably, such mRNA is not able to bind to small subunit of ribosome for effective translation due to the absence of normal cap structure [23, 24].

We have found also an interesting specific effect of Rbv on the formation of viral DNAcontaining intranuclear inclusion bodies. At concentrations inhibiting the synthesis of structural viral polypeptide, Rbv prevented the formation of inclusion bodies (observed in $67 \%$ of infected non-treated cells). However, at 31 $\mu \mathrm{g} / \mathrm{ml}$ concentration only early fine-grained inclusions generated in the initial stages of viral reproduction (18 $\mathrm{h}$ post infection) were formed in $16 \%$ of cells (Fig. 4C). However, the inclusions of late types (granular and large granular, unformed and formed centronuclear, Fig. 4B), which are typical for $48 \mathrm{~h}$ of adenovirus infected cells and correspond to the presence in nucleus of the mature infectious virions, were absent [12].

The data obtained on prevention of the transformation of early inclusions into the late ones also testify in favor of possible formation of proteins with changed structure affecting the assembly of virions.

Cyclocytidine $(\mathrm{CycloC})$ is a cytidine analogue, like 6-azaC, but contains an additional covalent bond between the cytosine and sugar moieties making its structure relatively rigid. 

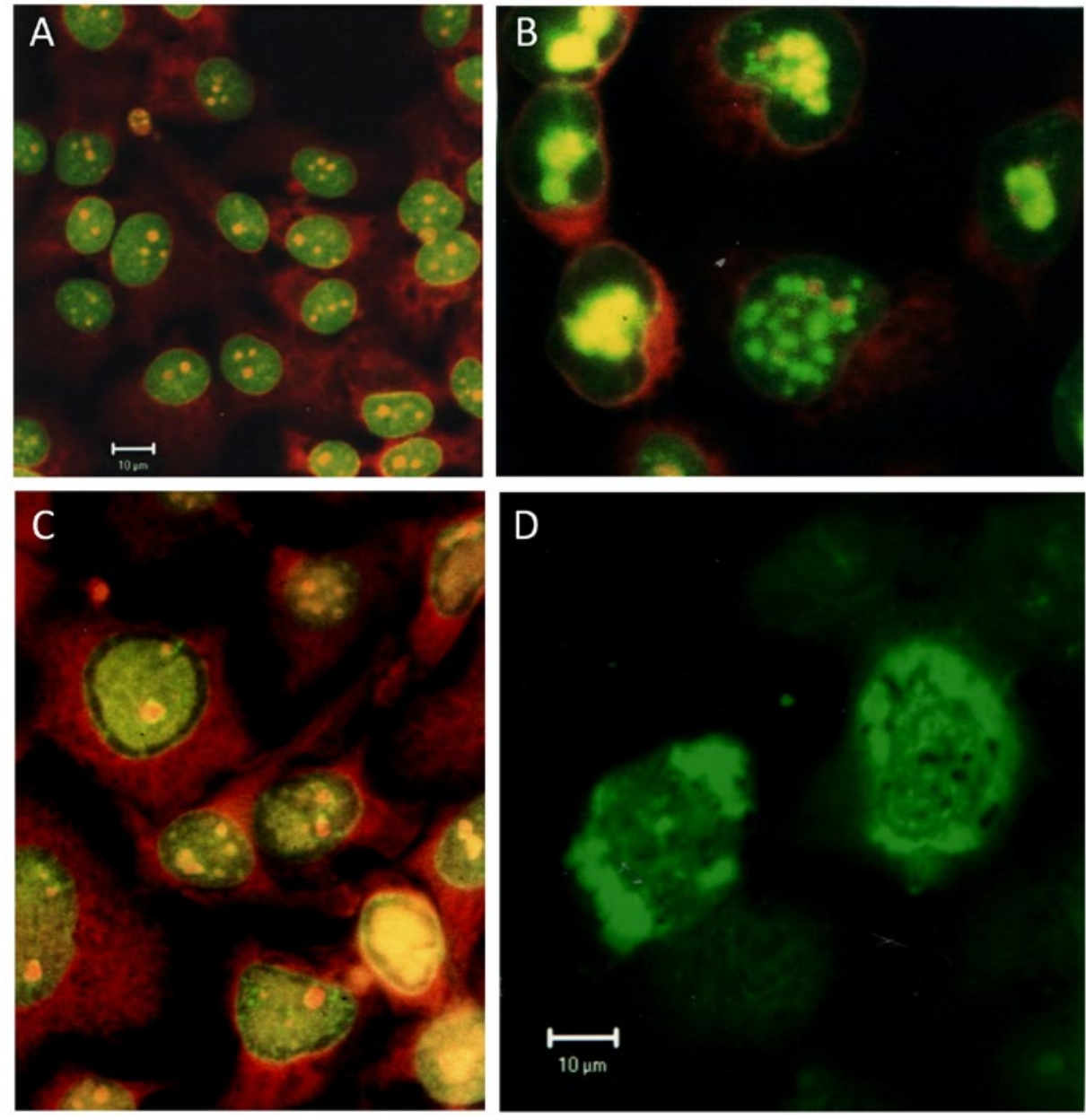

Fig. 4. Luminescent microscopy of HeLa cells with $0.01 \%$ acridine orange staining. $A-$ non-infected cells; $B-\mathrm{HeLa}$ cells infected with adenovirus (48 h p.i.); virus-induced intranuclear inclusion bodies of late types are observed; $C-\mathrm{HeLa}$ cells infected with adenovirus and treated by $\mathrm{Rbv}$ $(31 \mu \mathrm{g} / \mathrm{ml}, 48 \mathrm{~h}$ p.i.), intranuclear inclusion bodies of early types are observed; $D$ - detection of hexon antigen by indirect immunofluorescent staining.
The effect of CycloC on the synthesis of viral polypeptides is shown in Fig. 5. The synthesis of polypeptides of structural proteins was completely suppressed by CycloC at concentration $125 \mu \mathrm{g} / \mathrm{ml}$ (lane 3). However, the cells were still able to express early $72 \mathrm{~K}$ DNA-binding protein (DBP) for which mRNA is transcribed from the parent viral DNA. It is known that its synthesis takes place before the replication stage and is encoded by early region E2A [25]. This protein is necessary for the replication and elongation of viral DNA.
At a decrease of CycloC concentration to $31 \mu \mathrm{g} / \mathrm{ml}$ the synthesis of $72 \mathrm{~K}$ protein continues along with some structural viral polypeptides (II, IIIa, V) and $100 \mathrm{~K}$ protein, the synthesis of which depends on the replication of viral DNA (Fig. 5, lane 4). At the same time, the polypeptides III, IV, VI and VII are not synthesized. In the presence of low concentrations of CycloC (1.0 and $0.1 \mu \mathrm{g} / \mathrm{ml}$, lanes 5 and 6) the synthesis of early $72 \mathrm{~K}$ DBP stopped and the synthesis of all spectrum of the structural polypeptides was restored. 


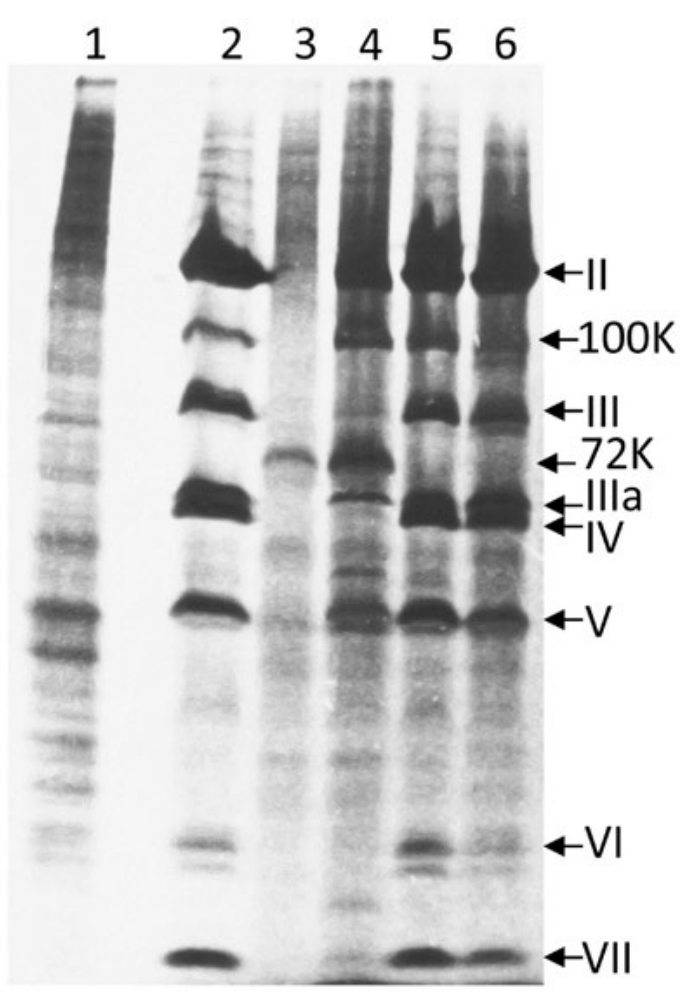

Fig. 5. Gel electrophoresis of adenoviral polypeptides synthesized in HeLa cells in the presence of CycloC, 48 $\mathrm{h}$ after infection (autoradiogram). Lane 1 - non-infected cells; lane 2 - infected cell; lanes 3-6 - infected cells treated with CycloC: 125 (3), 31 (4), 1 (5) and $0.1(6) \mu \mathrm{g} /$ $\mathrm{ml}$; II, III, IIIa, IV, V, VI, VII - polypeptides of structural adenoviral proteins; $100 \mathrm{~K}$ and $72 \mathrm{~K}$ - nonstructural viral polypeptides.

Noteworthy, after the onset of DNA replication, the activation of the ADV major late promoter leads to the expression of late genes. Late transcription unit is transcribed from the united late promoter as a large precursor (from 16.3 to 92 of units map) [25]. After its processing, five families of mRNA are formed: $\mathrm{L}_{1}, \mathrm{~L}_{2}, \mathrm{~L}_{3}, \mathrm{~L}_{4}$ and $\mathrm{L}_{5}$. They encode the viral structural proteins and the proteins required for encapsidation and maturation of virus particles.

Interestingly, the polypeptides III and VII from the mRNA family $L_{2}$ were absent, whereas the polypeptide $\mathrm{V}$ from this family was actively synthesized. Similar observation was made for the polypeptide VI from mRNA family $L_{3}$ : its synthesis did not occur whereas the polypeptide II was synthesized. This could be explained by non-simultaneous formation of mRNAs of different proteins and their functional activity at different periods. The absence of synthesis of the polypeptide IV, a sole representative of $\mathrm{L}_{5}$ family, may result from its distant location from the other mRNA families of the united transcript due to the separation by the early region E3 and the presence of additional leader segment at position 79 of the units map [25].

With a decrease of the CycloC concentration to $1.0 \mu \mathrm{g} / \mathrm{ml}$, the switch-off of early function of the viral genome and complete re-establishment of the late function were observed. It demonstrated the loss of CycloC activity at low concentrations. In addition to the synthesis of polypeptides II, IIIa, V and $100 \mathrm{~K}$, the previously absent polypeptides of other structural proteins (III, IV, VI, VII) were also synthesized under these conditions.

The obtained data confirm the necessity of $72 \mathrm{~K}$ DBP at the initial stage of replication, as well as during the continuation of the cycle. It is important to note that the formation of intranuclear inclusion bodies was revealed only at the restoration of the synthesis of the entire spectrum of structural polypeptides. At the concentration of CycloC $1.0 \mu \mathrm{g} / \mathrm{ml}$ the inclusion bodies were discovered in $80 \%$ of cells. 


\section{Conclusion}

We have established the peculiarities of the effect of three structurally diverse nucleoside analogues on the synthesis of adenoviral polypeptides in cell cultures. Two of three compounds, 6-AzaC and CycloC, are cytidine analogues whereas $\mathrm{Rbv}$ is a guanosine analogue. 6-azaC and Rbv contain a single covalent (glycosidic) bond with aglycone, so their conformational flexibility is much higher than that of Cyc1oC where the heterocycle is linked with sugar by two chemical bonds to form a tricyclic structure.

At concentrations known to inhibit the ADV all three compounds completely suppress the synthesis of polypeptides of the structural proteins.

The highest activity is demonstrated by 6-azaC. This compound completely blocked the synthesis of polypeptides at the concentration range $125-8 \mu \mathrm{g} / \mathrm{ml}$. In contrast to Rbv and CycloC demonstrating the inhibitory effect in triphophate form, 6-azaC is not phosphorylated but can form a complex with DNA. In such a way, this nucleoside analogue inhibits the replication of DNA, transcription and, as a result, blocks the synthesis of viral polypeptides.

CycloC was active only at $125 \mu \mathrm{g} / \mathrm{ml}$, turning off the synthesis of polypeptides of structural proteins, but being unable to inhibit the synthesis of early DBP $72 \mathrm{~K}$, which is necessary both at the beginning of replicative step and during the synthesis of structural polypeptides. Upon the decrease of drug concentration, the synthesis of these polypeptides is gradually restored, although their RNA is transcribed from the united late promoter as a large precursor.
Rbv, just like 6-azaC, inhibited the synthesis of viral polypeptides, but at higher concentrations. The characteristic feature of this compound is its ability to disturb the formation of structural proteins consisting of several polypeptides, and thus probably the assembly of the virions. In particular, Rbv disturbs the hexon trimerization and the formation of immunologically active hexon.

Thus, all tested nucleoside analogues are able to suppress the synthesis of adenoviral polypeptides that could be the basis for the development of antiviral therapies. At the same time, the specific patterns of biological activity of these compounds significantly differ being determined by their structure and concentration.

\section{Acknowledgement}

Authors are grateful to Dr. Igor Dubey for valuable discussion and critical review of the manuscript.

\section{REFERENCES}

1. Nosach $L N$. Adenoviral infection and prospects for chemotherapy. Prophylactic Med. 2011;13 (1): 66-72.

2. Nosach LN, Butenko SI, Thimofeeva MYa, Dyachenko NS, Thichomirova TP, Alexeeva IV, Chernetskij VP. [An analysis of the DNA synthesized in adenovirus-infected cells under exposure to nucleoside analogs]. Mikrobiol Zh. 1989; 51(6): 73-5.

3. Alexeeva I, Dyachenko N, Nosach L, Zhovnovataya V, Rybalko S, Lozitskaya R, Fedchuk F, Lozitsky V, Gridina T, Shalamay A, Palchykovskaya L, Povnitsa O. 6-Azacytidine - compound with wide spectrum of antiviral activity. Nucleosides Nucleotides Nucleic Acids. 2001; 20(4-7): 1147-52.

4. Zarubaev VV, Slita AV, Sukhinin VP, Nosach LN, Dyachenko NS, Povnitsa OY, Zhovnovataya VL, 
Comparative analysis of the effect of 6-azacytidine, ribavirin and cyclocytidine on the synthesis of adenoviral polypeptides

Alexeeva IV, Palchikovskaya LI. Effect of 6-azacytidine on the course of experimental adenoviral infection in newborn Syrian hamsters. $J$ Chemother. 2007; 19(1): 44-51.

5. Zarubaev $V V$, Garshinina AV, Kalinina NA, Shtr-o AA, Belyaevskaya SV, Slita AV, Nebolsin VE, Kiselev OI. Activity of Ingavirin 6-[2-(1H-imidazol4-yl)ethylenamino]-5-oxohexanoic acid\} against human respiratory viruses in vivo experiments. Pharmaceuticals. 2011; 4(12): 1518-34.

6. Alexeeva IV, Nosach LN, Palchykovska LG, Usenko LS, Povnitsa OY. Synthesis and comparative study of anti-adenoviral activity of 6-azacytidine and its analogues. Nucleosides Nucleotides Nucleic Acids. 2015; 34(8): 565-78.

7. Alexeeva $I V$, Palchikovskaya LG, Shalamay $A S$, Nosach LN, Zhovnovataya VL, Povnitsa OY, Dyachenko NS. N4-Amino-acid derivatives of 6-azacytidine: structure-activity relationship. Acta Biochim Polon. 2000; 47(1): 95-101.

8. Alexeeva IV, Palchikovskaya $L G$, Usenko LS, Nosach LN, Zhovnovataya VL, Dyachenko NS. The glycosilic analogues of 6-azacytidine: synthesis and antiviral activity. Biopolym Cell. 2004; 20(5): 435-9.

9. Tschilevich TL, Shuchaveleva IL, Nosach LN, Zhovnovataya VL, Smirnov TP, Kochetkova SV, Gottikh BP, Florentiev Vl. Acyclic analogues of ribavirine. Synthesis and antiviral activity. Bioorg Chem. 1988, 14(5):689-93.

10. Nosach L, Dyachenko N, Zhovnovataya V, Tarassishin L, Povnitsa O, Mashkovsky N, Lidak M, Cherneckiy $V$. The effect of anomal nucleosides on the reproduction of adenovirus type 1 and the synthesis of viral polypeptides. Antiviral Substances. Riga. 1982; 151-2.

11. Nosach $L N$. Antiadenoviral assay based on the quantitative detection of infected cells containing virusinduced intranuclear inclusion bodies. Antiviral Res. 2011; 90(2): 134 (A61).

12. Nosach LN, Dyachenko NS. Cytopatologya of adenovirus infection. Kyiv; Naukova dumka, 1982: 124p.

13. Anderson $C W$, Baum $S G$, Gesteband RF. Processing of adenovirus 2 induced proteins. Virol. 1973; 12(2): 241-58.
14. Mentel R, Kurek S, Wegner U, Janta-Lipinski M, Gürtler L, Matthes E. Rnhibition of adenovirus DNA polym-rase by modified nucleoside triphosphate analogues correlate with their antiviral effects on cellular level. Med Microbiol Immunol. 2000; 189(2): 91-5.

15. Naesens L, Lenaerts L, Andrei G, Snoeck R, Van Beers D, Hole A, Balzarini J, De Clercq E. Antiadenovirus activities of several classes of nucleoside analogues. Antimicrob Agents Chemother. 2005; 49(3): 1010-6.

16. D'Crus OJ, Uscun FM. Stampidine: a selective oculo-genital microbicide. J Antimicrob Chemother. 2005; 56(1):10-9.

17. Lenaerts L, De Clercq E, Naesens L. Clinical feature and treatment of adenovirus infection. Rev Med Virol. 2008; 18 (6):357-74.

18. $R$ Van Rompay, Ameli Norda, Kavin Linden, Magwus Johansson, Anna Karlsson. Phosphorylation of uridine and cytidine nucleoside analogues by two human uridine-cytidine kinases. Mol Pharmacol. 2001, 59(5):1181-6.

19. Mishchuk YaR, Potyagaylo AL, Hovorum DM. Structure and dynamics of 6-azacytidine by $\mathrm{MNDO} / \mathrm{H}$ quantum-chemical method. J Mol Struct. 2000; 552(1-2): 283-9.

20. Platonov MO, Hovorun DM, Alexeeva IV, Sudakov OO, Boyko YuV, Palchykovska LH. Nonempirical quantum-chemical conformational analysis of 6-azacytidine - a modifited nucleoside of wide spectrum of biological activity. Dop Natl Acad Sci Ukraine. 2004; (3): 163-9.

21. Iermak IeL, Kruglova OB, Palchykovska LH, Alexeeva IV. Spectrophotometrical study of mechanism of cytidine analogues and ethidium bromide binding with DNA. Biopolym Cell. 2007; 23(6): 529-37.

22. Gladkovskaya NA, Iermak IeL, Kruglova OB, Palchykovskaya LI, Alexeeva IV. 6-Azacytidine binding to DNA-moleculs. Biophysic Bull. 2008.21(2):19-28.

23. Sidwell $R W$. In vitro and in vivo inhibition of DNA viruses by ribavirin. (Ed. Smith RA, Knight V, Smith JAD). Academic Press, 1984: 19-32.

24. Graci JD, Cameron CE. Mechanisms of action of ribavirin against distinct viruses. Rev Med Viral. 2006; 16(1): 37-43. 
25. Sharp P. Adenovirus transcription. In: The adenoviruses. Ed. Ginsberg H. New-York: Plenum Press, 1984; 179-204.

\section{Порівняльний аналіз впливу 6-азацитидину, рибавірину та циклоцитидину на синтез аденовірусних поліпептидів}

Л. М. Носач, Л. С. Усенко, І. В. Алексєєва

Мета. Провести порівняльний аналіз впливу антивірусних аналогів природних нуклеозидів 6-азацитидину (6-AzaC), рибавірину (Rbv) та циклоцитидину (CycloC) на синтез аденовірусних (ADV) поліпептидів у культурі клітин. Методи. Люмінесцентна мікроскопія; імунофлуоресцентний метод виявлення антигена гексону; електрофорез ${ }^{14} \mathrm{C}$-мічених білків в SDSполіакриламідному гелі. Результати. 6-AzaC i Rbv здатні повністю блокувати експресію аденовірусного геному, про що свідчить інгібування ними синтезу як ранніх, так і пізніх поліпептидів. Rbv також пригнічує утворення імунологічно активних тримерів гексону та внутрішньоядерних включень пізнього типу. Сус1оC впливає на функціональну активність аденовірусного геному іншим чином: він може повністю блокувати прояви пізньої функції геному, але не впливає на ранню, проявом якої є синтез ДНК-зв'язувального білка $72 К$. Лише після синтезу повного спектру поліпептидів структурних білків та формування внутрішньоядерних включень пізнього типу синтез цього білка зупиняється. Висновки. Встановлено особливості впливу нуклеозидних аналогів на синтез аденовірусних поліпептидів. Усі досліджені нуклеозиди здатні пригнічувати його, проте специфічні профілі їх біологічної активності визначаються структурою та концентрацією сполук.

К л ю ч о в і с л о в а: аденовірус, 6-азацитидин, рибавірин, циклоцитидин, вірусні поліпептиди.

\section{Сравнительный анализ влияния 6-азацитидина, рибавирина и циклоцитидина на синтез аденовирусных полипептидов}

\author{
Л. Н. Носач, Л. С. Усенко, И. В. Алексеева
}

Цель. Провести сравнительный анализ влияния противовирусных аналогов природных нуклеозидов 6-азацитидина (6-AzaC), рибавирина (Rbv) и циклоцитидина (CycloC) на синтез аденовирусных (ADV) полипептидов в культуре клеток. Методы. Люминесцентная микроскопия; иммунофлуоресцентный метод выявления антигена гексона; электрофорез ${ }^{14} \mathrm{C}$ - меченых белков в SDS-полиакриламидном геле. Результаты. 6-AzaC и Rbv способны полностью блокировать экспрессию аденовирусного генома, о чем свидетельствует ингибирование синтеза как ранних, так и поздних полипептидов. Rbv также подавляет образование иммунологически активных тримеров гексона и внутриядерных включений позднего типа. Сус1оС влияет на функциональную активность аденовирусного генома по-другому: он может полностью блокировать проявление поздней функции генома, но не влияет на раннюю, выражающуюся в наличии синтеза ДНКсвязывающего белка 72К. Синтез этого белка останавливается только после синтеза полного спектра полипептидов структурных белков и формирования внутриядерных включений позднего типа. Выводы. Установлены особенности влияния нуклеозидных аналогов на синтез аденовирусных полипептидов. Все исследованные нуклеозиды способны подавлять его, однако специфические профили их биологической активности определяются структурой и концентрацией соединений.

Кл юче в ы е с л о в а: аденовирус, 6-азацитидин, рибавирин, циклоцитидин, вирусные полипептиды

Received 04.04.2020 